\title{
BTY Göstergeleriyle Dış Kaynaklı Yazılım Lokasyonlarını Değerlendirmek için Bir Karar Destek Aracı: Pakistan Örneği
}

\author{
Muhammet Ali Kadıoğlu ${ }^{1^{*}}$ \\ 1* İstanbul Teknik Üniversitesi, Lisansüstü Eğitim Enstitüsü, Endüstri Mühendisliği Bölümü, İstanbul, Türkiye, (ORCID: 0000-0002-3402-7362), \\ kadioglu19@itu.edu.tr
}

(2nd International Conference on Access to Recent Advances in Engineering and Digitalization (ARACONF)-10-12 March 2021)

(DOI: $10.31590 /$ ejosat.903665)

ATIF/REFERENCE: Kadığlu, M.A. (2021). Dış Kaynaklı Yazılım Geliştirme Süreçleri İçin Lokasyon Değerlendirmesi: Bir Örnek Lokasyon İncelemesi. Avrupa Bilim ve Teknoloji Dergisi, (24), 405-415.

$\ddot{O} z$

Teknoloji şirketlerinde yöneticiler, gelişen ve büyüyen dünyada her gün şirketleri adına önemli stratejik kararlar verirler. Yazılım geliştirme süreçleri ile çeşitli uygulamalar geliştiren teknoloji şirketleri için birçok alternatif kaynak ve konum bulunmaktadır. Giderlerin büyük çoğunluğunu insan kaynağına yapılan yatırımların meydana getirdiği bu şirketler, dış kaynak kullanımı ile maliyetleri azaltma, nitelikli insan kaynağına ulaşma, pazarda iş ve müşteri odaklı konumlanma, pazara yakın olma vb. nedenler ile yazılım geliştrime süreçlerinde alternatif dış kaynakları kullanmaya yönelebilmektedirler. Bu çalışmada, yöneticilerin BTY (Bilim, Teknoloji ve Yenilik) göstergeleri ile yazılım geliştirme süreçlerinde dış kaynak kullanımı için belirledikleri potansiyel lokasyonları değerlendirebilecekleri bir karar destek sistemi tasarlanmıştır. Ayrıca, örnek bir lokasyon olarak gelişmekte olan ülkeler arasında yer alan Pakistan incelenmiştir. Değerlendirme için seçilen Pakistan ile hızlı bir gelişim içerisinde olan ve en önemli dış lokasyonlar arasında bulunan BRICS (Brezilya, Rusya, Hindistan, Çin, Güney Afrika) ülkeleri karşılaştırılmıştır. Çalışma da belirlenen anahtar göstergeler, değerlendirilmesi planlanan alternatif lokasyonlar için özelleştirilebilir.

\section{A Decision Support Tool to Evaluate Software Outsourcing Locations with STI Indicators: A Case Study, Pakistan}

\begin{abstract}
Managers in technology companies make substantial strategic decisions on behalf of their companies every day in the developing and growing world. There are many alternative resources and locations for technology companies that develop various applications with software development processes. These companies, where most of the expenses are made by investments in human resources, are to reduce costs through outsourcing, to reach qualified human resources, to be business and customer-oriented in the market, to be close to the market, etc. For reasons, they may tend to use alternative external resources in software development processes. In this study, a decision support system has been designed where managers can evaluate the STI (Science, Technology, and Innovation) indicators and potential locations they have identified for outsourcing in software development processes. In addition, Pakistan, which is among the developing countries, was examined as an exemplary location. Pakistan was selected for evaluation with BRICS (Brazil, Russia, India, China, South Africa) countries, which are in rapid development and are among the most significant external locations, were compared. Key indicators determined in the study can be customized for alternative locations that are planned to be evaluated.
\end{abstract}

Keywords: Decision Support Tool, STI Indicators, Software Outsourcing, BRICS, Pakistan.

\footnotetext{
*Sorumlu Yazar: kadioglu19@itu.edu.tr
} 


\section{Giriş}

Dış kaynak kullanarak yazılım geliştirme süreçleri, yurt içinde ve dışında olmak üzere iki temel gruba ayrılabilir. Yurt içi dış kaynak kullanımı, şirketler arasında yürütülen faaliyetlerin ülke sınırları içerisindeki dış kaynaklardan elde edilmesini ifade etmektedir. $\mathrm{Bu}$ şirketler coğrafi ve kültürel açının sağladığ avantajları kullanırlar; böylece birbirleriyle daha kolay temas kurarlar, yurtdışına göre daha hızlı adapte olurlar ve genellikle dil ve kültür problemi yaşamadan geliştirme süreçlerine başlayabilirler. Ancak yakın lokasyonların dış kaynaklı yazılım süreçlerinde kullanılması şirketlerin birtakım avantajlardan da yararlanamamalarına neden olabilir. Günümüzde giderek artan ilgi ve talep ile yurtdışı kaynak kullanımı diğer grubu temsil etmektedir. Yurtdışı kaynak kullanımı, bir firmanın başka bir ülkede yazılım geliştirme süreçlerinin bir kısmını veya tamamını gerçekleştirmek için harici bir organizasyon işe alması ve yazılım ihtiyaçlarını yurt dışındaki bir kaynaktan sağlamasıdır. $\mathrm{Bu}$ dış kaynak kullanımı, küreselleşen dünyada pazar avantajından yararlanmak isteyen firmaların yükselişinde büyük pay sahibi olmaktadır. Yurtdışından sağlanan dış kaynak kullanımı ile Bilgi Teknolojileri endüstrisindeki rekabet artmıştır. $\mathrm{Bu}$ artış; düşük maliyet, yüksek nitelikli personel kullanımı, gelişmiş hizmet kalitesi, müşteriye hızlı teslimat ve yeni pazarlara erişim gibi faydalardan yararlanmak için yazılım geliştiren firmaları dış kaynak kullanımına teşvik etmiştir (Ishenko, 2005). Bu çalışma, teknoloji şirketlerindeki karar vericilere destek olması amacıyla diş kaynaklı yazılım kullanılırken potansiyel lokasyonların değerlendirilmesinde Bilim, Teknoloji ve Yenilik (BTY) göstergelerinin kullanılmasına sistematik bir bakış sunmayı amaçlamıştır.

Yazılım endüstrisi nitelikli insan gücünün yüksek iş bilgisi seviyesi, asıl işine odaklanarak geliştirme süreçlerinde bireysel çalışabilmesi bakımından uzaktan çalışmaya en kolay adapte olan sektörlerden biri olmuştur. İnsan kaynağı için alternatif çözüm arayışı içerisindeki şirketlerin bulundukları lokasyon ile dış kaynak kullanılacak lokasyon arasındaki yüksek ücret farkları ve işin tekrarlayan doğası gereği yazılımın yurtdışında geliştirilmesi önemli bir firsat olarak görülmektedir. Ayrıca, bilgi ve iletişim teknolojilerinde, özellikle bulut teknolojilerinin gelişmesi ile yazılımın hizmet olarak sunulabilmesi, sürekli gelişim ve entegrasyon araçlarının gelişmesi, düşük maliyetlerle lokasyondan bağımsız yazılım geliştirmeye olanak sağlamıştır (Ishenko, 2005). 2018'de dünyada bilgi teknolojilerinde diş kaynak kullanımı 62 milyar \$, operasyonel süreçlerde dış kaynak ise 23,6 milyar \$ olmak üzere toplamda 85,6 milyar \$ olarak gerçekleşmiştir (Liu, 2019). Firmaların dış kaynak kullanarak iş ihtiyaçlarını karşılarken belirledikleri stratejilerde bilgi teknolojilerinin asıl belirleyici olduğu görülmektedir. $\mathrm{Bu}$ kapsamda alternatif lokasyonların analiz edilebilmesi ve değerlendirilmesi ciddi bir ihtiyaç haline gelmektedir. BTY göstergeleri ile dış kaynaklı yazılım geliştirme süreçlerinde olası lokasyonların değerlendirilmesi önem kazanmaktadır.

Dış kaynak kullanımı ile yazılım geliştirme hedeflerine ulaşılması şirketler için bir başarı kriteri olarak kabul edilmektedir. Kamu tarafından hayata geçirilen BTY politikaları, özel sektör tarafından gerçekleştirilen araştırma ve geliştirme faaliyetleri, üniversitelerin sanayi ile kurcağı iş birlikleri gibi bir çok etken bu potansiyeli gerçekleştirmede kritik rol oynamaktadır. Devletler teknolojik ve yenilikçi yeteneklerin geliştirilmesi için çeşitli teşviklerde bulunmaktadırlar. Gelişmiş
BTY yeteneklerine sahip ülkelerin yaptığı gibi sıklıkla yenilikçiliği teşvik etmek bunlardan biridir. Ayrıca teknolojik ve yenilikçi firsatların ve pazarların gelişimini desteklenmek, dış kaynaklı yazılım lokasyonlarını cazibe merkezi haline getirmektedir. Ülkelerin uygulayacağı BTY politikaları sadece ekonomik büyümeyi desteklemekle ve dış kaynaklı yazılım lokasyonlarını geliştirmekle kalmamakta, aynı zamanda vatandaşların refahını yükselten bilgi, teknoloji ve yeniliklere erişimi de kolaylaştırmaktadır (ESCAP, 2018).

$\mathrm{Bu}$ çalışma kapsamında ülkelerin sahip olduğu bilgi teknoloji ve yenilikçilik potansiyellerinin belirlenmesi amacıyla ilk olarak BTY istatistikleri UNESCO İstatistik Enstitüsü, Dünya Fikri Mülkiyet Organizasyonu (WIPO) ve Dünya Bankası veri tabanlarından toplanmış ve bir veri havuzunda bir araya getirilmiştir. Veri toplama aşamasından sonra çalışmada kullanılan lokasyon analizi açıklanmış, karşılaştırılacak parametrelerin nasıl belirlendiği ifade edilmiştir. Elde edilen verilerin sınıflandırılması ve analiz aşaması için görselleştirme anlatılmıştır. İkinci bölümde oluşturulan karar destek aracı ile Pakistan ve BRICS (Brezilya, Rusya Federasyonu, Hindistan, Çin ve Güney Afrika) ülkeleri, belirlenen parametreler ile değerlendirilmiştir. D1ş kaynak kullanımı için belirlenen lokasyonun finansal ve insan kaynakları, IP, bilimsel yayın ve ihracatına ait istatistikleri incelenerek değerlendirilen ülkenin profili çıkarılmıştır. Son bölümde çalışma çıktıları ve bulgular değerlendirilmiş, önerilerde bulunulmuş ve yöntemin kullanım alanları paylaşılmıştır.

\section{Materyal ve Metot}

\subsection{Lokasyon Seçimi}

Gartner tarafından yapılan araştırmaya göre Asya-Pasifik (APAC) bölgesinde gelişmekte olan pazarlar 2 seviyede incelenmektedir. Ayrica bu iki gruba ek olarak potansiyel vadeden ülkeler belirlenmektedir. Myanmar ve Pakistan potansiyel vadeden ülkeler arasında yer almaktadır. Her ikisi de daha ucuz ülkelere yatırım yapmayı düşünen şirketler için alternatif bir cazibe merkezi olarak ideal şartlar yaratmaya başlamışlardır ve halihazırda yerel pazarlarının dışında yazılım hizmeti satan servis sağlayıcılar için uygun lokasyonlar olarak değerlendirilmektedir (Longwood ve ark., 2015). Pakistan Yazılım İhracat Kurulu (PSEB) ve Pakistan devleti, ülkelerini bir denizaşırı platform olarak konumlandırmak için çalışmalar yürütmektedirler (Roy ve ark., 2008). Pakistan, birçok denizaşırı lokasyondan daha uygun insan gücü istihdam etme ve ucuz altyap1 maliyetleri ile rekabetçi bir pazar olarak ön plana çıkabilir. Bu çalışmada Pakistan'ın dış kaynaklı yazılım kullanmak isteyen şirketler için avantajları değerlendirilmiş ve potansiyeli belirlenmeye çalışılmıştır. Firmaların dış kaynak kullanarak yazılım geliştirme süreçlerini gerçekleştirecekleri lokasyonu seçerken kullanabilecekleri karar destek aracı Pakistan örneğinde kullanılmıştır.

BRICS ülkeleri (Brezilya, Rusya Federasyonu, Hindistan, Çin ve Güney Afrika), gelişmekte olan ülkeler arasında hızla yükselen ülkelerdir. BRICS ülkeleri için yenilik endeksi incelendiğinde ortalama puanlarında 2017-2025 yıllarında kayda değer bir artış öngörülmektedir. Bu artışın nedeni olarak ulusal yeniliklerin genel rekabet gücünü sürekli olarak geliştirmesi tahmin edilmektedir (BRICS Innovative Competitiveness Report, 2017). Ayrıca BRICS ülkeleri Gartner tarafından yakın ve uzak dış kaynak lokasyonlarının değerlendirildiğgi bir çalışmada en önemli 30 dış kaynak lokasyon arasında 406 
listelenmektedir (Longwood ve ark., 2015). Dış kaynak lokasyonları arasında yakaladıkları başarı ve hızlı gelişim ile BRICS ülkeleri, Pakistan'ın değerlendirilmesinde karşılaştırma yapılacak örnek grup olarak seçilmiştir.

\subsection{Veri Toplama}

UIS Stat, UIS verilerini ve göstergelerini görüntülemek için güçlü ve kullanımı kolay bir tarayıcı sağlar. Veriler konusuna göre ağaç görünümünde düzenlenmiş, basit ve üç boyut formatında (gösterge, ülke veya bölge, yıl) sunulmaktadır. Kullanıcılar kendi özel tablolarını olușturabilir ve verileri dıșa aktarabilir (UIS Stat, 2019). Bu veri taban1, BTY göstergelerinden finansal ve insan kaynakları hakkında istatistikler elde edilmesinde kullanılmıştır.

Fikri mülkiyet (IP) istatistikleri, dünyadaki politika, işletme ve teknolojideki eğilimleri anlamak için kullanılabilecek temel araçlardan biridir. Dünya Fikri Mülkiyet Teşkilatı (WIPO), en güncel küresel IP verilerini sağlamak için dünya genelindeki IP ofisleriyle çalışmaktadır. Ayrıca, küresel IP faaliyetleri ve uluslararası IP haklarını korumak için WIPO tarafindan yönetilen anlaşmaların kullanımı hakkında istatistiksel raporlar yayınlamaktadır. WIPO Fikri Mülkiyet İstatistikleri Veri Merkezi, WIPO'nun dünya çapındaki fikri mülkiyet faaliyetleri hakkındaki kapsamlı istatistiklere erişim sağlayan ücretsiz bir çevrimiçi hizmet sunmaktadır. Herhangi bir kullanıcı çok çeşitli göstergeler kullanarak arama yapabilir, ihtiyaç duyduğu kısıtlara göre en yeni ve en güncel verilere erişebilir (WIPO, 2019). BTY göstergelerinin bir çıktısı olarak fikri mülkiyet istatistikleri, WIPO Fikri Mülkiyet İstatistikleri Veri Merkezi'nden alınmıştır.

Dünya Bankası, ülkelerin çoğundaki kalkınma durumları hakkında ayrıntılı veri setlerine ücretsiz ve açık erişim sağlamaktadır. Dünya Bankası veri tabanı alt kümeleri ile sunulan veriler ve zaman çizelgeleri ile geniş bir koleksiyonu barındırmaktadır. Dünya Bankası, şeffaflık ve hesap verilebilirliğin kalkınma sürecinde gerekli olduğunu ve Banka'nın yoksullukla mücadele misyonu için gerekli olduğunun farkındadır. $\mathrm{Bu}$ verilere daha geniş erişim, politika yapıcıların daha bilinçli kararlar vermelerini ve iyileştirmeleri daha doğru değerlendirmelerini sağlar (The World Bank, 2019). Şirketlerdeki karar vericilerinde bu veri setlerinden yararlanarak dış kaynaklı yazılım lokasyonlarını değerlendirken kullanabilecekleri karar destek arac1, akademik, finansal kaynaklar ve IP istatistiklerinin takibinde bu veri tabanından nasıl yararlanılabileceği bu çalışma örneklendirilmiştir.

Sorumluluk alanlarına göre belirlenmiş kamu kuruluşları tarafından sağlanan BTY verileri, Pakistan ve BRICS ülkelerinin karşılaştırılabilmesi için işlenerek yeni bir veri tabanı oluşturulmuştur. Benzer şekilde oluşturulacak veri tabanları, karar vericiler için bir araç olarak kullanılabilmektedir ve gelecek dönemde yapılacak değerlendirmeler için bir kaynak teşkil etmektedir.

\subsection{Veri Analizi}

Organizasyonel yapılar ülkeler arasında büyük farklılıklar gösterebildiğinden, sınırlı sayıda gösterge kullanılarak lokasyonların performans karşılaştırmaları yapılmıştır. $\mathrm{Bu}$ araştırmada, dış kaynak kullanılarak yazılım geliştirme süreçlerinde lokasyon değerlendirmesi için Pakistan örneği ele alınmış ve BRICS ülkeleri ile karşılaştırılmıştır.

- $\quad$ Finansal Kaynaklara ait İstatistikler - BTY Girdileri - Ar-Ge Yatırımları

e-ISSN: 2148-2683
- Ar-Ge Harcamaları

- Ar-Ge Harcamalarının GSYİH'ye Oranı

- Kişi başına düşen Ar-Ge Harcaması

- Sektörler Bazında Ar-Ge Harcamaları

- Finans Kaynağına Göre Ar-Ge Harcamaları

- İnsan Kaynaklarına ait İstatistikler - BTY Girdileri

- Ar-Ge Personeli

- Toplam Ar-Ge personeli sayısı

- Milyon kişi başına düşen toplam Ar-Ge personeli

- Bin çalışan başına düşen toplam Ar-Ge personeli

- Ar-Ge personelinin Sektörlere Göre Dağılımı

- Araştırmacılar

- Toplam araştırmacı sayısı

- Araştırmacıların sektörlere göre dağılımı

- Meslek grubuna göre Ar-Ge personeli incelendiğinde mühendislik ve teknoloji alanında çalışanların sayısı

- IP İstatistikleri - BTY Çıktıları

○ Patent

- Patent Başvuruları

- Alınan Patentler

○ Ticari Markalar

- Ticari Marka Başvurularında Belirtilen Sinıf Sayısı

- Marka Tescillerinde Belirtilen Sinıf Sayısı

- Bilimsel Yayın İstatistikleri - BTY Çıktıları

- Bilimsel ve teknik dergi makaleleri

- İhracat İstatistikleri - BTY Çıktıları

○ Yüksek teknoloji ihracatı

- Yüksek teknoloji ihracatının yapılan toplam üretim ihracatına oranı

Çalışmada yer alan lokasyonların karşılaştırılmasında son on yıllık trend, değerlendirme için esas alınmıştır. Ayrıca, karşılaştırma yapılan lokasyonların oluşturduğu kümede, BRICS ülkelerinde, herhangi bir ülkeye ait eksik verilerle karşılaşıldığında, mevcut veriler üzerinden ortalama değer hesaplanmış ve karşılaştırma bu şekilde yapılmıştır. Karşılaştırma yapılabilmesi için her iki inceleme grubununda sahip oluğu ölççümlerden yararlanılmıştır. Değerlendirme yapılacak lokasyonların bir önceki bölümde yer alan veri tabanlarına veri sağlamaları değişkenlik gösterebilmektedir.

Bileşik yıllık büyüme oranı (CAGR), büyümenin üssel olarak bileşik bir oranda gerçekleştiği varsayılarak, verilen iki yıl arasındaki yıllık ortalama artış veya azalış oranıdır. Verilen iki yıl arasındaki yıl sayısı

$$
\mathrm{N}=\mathrm{Z}-\mathrm{X}
$$

ile hesaplanır. $X$ ve $Z$ yılları arasındaki veriler trendin doğruluğunu destekleyici nitelikte olması beklenir. CAGR formülü, $\mathrm{t} 1$ ile $\mathrm{t} 10$ yıllarına ait bileşik yıllık büyüme oranı $=[(\mathrm{t} 1$. yıldaki değer/t10. Yıldaki değer) $\wedge(1 / \mathrm{N})-1]$ olarak Gartner tarafından ifade edilmiştir (Gartner Glossary).

\subsection{Veri Görselleştirme}

BRICS ülkeleri ile Pakistan'ın karşılaştırılması için kullanılan parametreler ve işlenen veriler değerlendirme aşamasında yorumlama sürecinin kolaylaştırışması için görselleştirilmiştir. Veri toplama ve analizi aşamasında 
görselleştirme için hazırlanan bu istatistiksel veri, MS PowerPoint üzeirnde çalışan Think cell aracı ile görselleştirilmiştir. Oluşturulan "stacked" ve "clustered" grafikleri, elde edilen ortalama değerler arasındaki farkı daha anlaşılır şekilde açıklamak ve yorumlamak için kullanılmıştır.

\section{Araştırma Sonuçları ve Tartışma}

\subsection{Finansal Kaynak İstatistikleri - BTY Girdilerinin Ölçülmesi}

Bilgi üretimi birçok yenilikçi politika aracının temelini oluşturmaktadır. Bu politikaların varlığını sürdürebilmesi ve devamlılığının sağlanabilmesi için bu üretime sahip çıkan ve destekleyen insan kaynağını oluşturmak ve bu insan kaynağının araştırma ve geliştirme kapasitesini artrımak kilit öneme sahiptir. Bir diğer önemli bileşen de yenilikçi süreçler için kamuda, üniversitelerde ve özel şirketlerde bilim ve teknolojiye finansal kaynak ayırmak ve teşvikler sunmak, yenilikçiliğin devamlılığını ve sürdürülebilirliğini geliştirmektir. BTY politikalarının finansal kaynaklarla destkelenmesine ulusal düzeyde, belirli stratejik teknoloji alanlarının geliştirilmesi için ülkelerin ayırdığ özel fonlar gösterilebilir (Schwachula ve ark., 2014). BTY göstergeleri dış kaynaklı yazılım lokasyonları incelenirken mevcut durumun analizinde finansal kaynakların kalkınmaya olan etkisi üzerinde durarak çeşitli içgörüler sağlamamıza zemin oluşturmuştur. Buna paralel olarak, finansal göstergeler BTY girdileri ve çıktılarına doğrudan ve dolaylı olarak etkilemektedir. $\mathrm{Bu}$ göstergelere dayanarak, herhangi bir lokasyonun bir yazılım geliştirme merkezi olarak değerlendirilmesine yönelik tasarlanan karar destek aracı, finansal durumun analizinde ve politikaları

\section{Şekil 1: Ar-Ge Harcamaları ('000 \$) (UNESCO İstatistik Enstitüsü Veri Tabanı)}

ulusal kalkınma gündeminin bir parçası olarak değerlendirmede rol oynayabilmektedir.

\subsubsection{Ar-Ge Harcamalart}

Araştırma ve geliştirme faaliyetleri başarılı bir yenilikçilik ve dolayısıyla rekabetçilik için ön şarttır. Kamu kuruluşlarındaki Ar-Ge birimleri, uzmanlaşmış devlet destekli araştırma enstitüleri, üniversiteler ve endüstri de dahil olmak üzere birçok kurumda araştırma ve geliştirme faaliyetleri yürütülmektedir. Bu kurumlar arasında çok sıkı bir örgütsel ve finansal bağ vardır. Ekosistem içerisinde yer alan her bir aktör Ar-Ge harcamalarından beslenir. Bunun yanında Ar-Ge harcamalarının yüksek olması ekonomik büyümenin hızlanmasını da sağlamaktadır. Ekonomik büyümenin yanında araştırma ve geliştirmeyi teşvik etmek ulusal güvenlik, prestij ve bilimsel merak gibi ekonomik getiriden daha fazla politik öneme sahip olabilmektedir (Vithlani, 2019). Şekil 1, Pakistan ve BRICS ülkelerindeki Ar-Ge harcamalarını göstermektedir. 10 yıllık dönemdeki mevcut durum analiz için görselleştirilmiştir. UNESCO 'ya göre, Pakistan'in 2017'deki toplam Ar-Ge harcaması yaklaşı 2.6 milyar Amerikan doları olarak gerçekleşmiştir. Son on yılda, Pakistan'daki Ar-Ge harcamalarında azalma eğilimi görülmektedir (-\% 4,56). Öte yandan, BRICS ülkelerindeki Ar-Ge harcaması ortalama yıllık \% 20.13 büyüme oranı ile yaklaşık 270 milyar dolara ulaşmıştır. Pakistan, BRICS ülkelerinde olduğu gibi Ar-Ge yatırımlarında yükseliş trendini yakalamasına yardımcı olacak BTY politikalarını yürütmeli ve ekonomik büyümesini Ar-Ge yatırımları ile destekleyerek sürüdürülebilir büyümeyi sağlamalıdır.

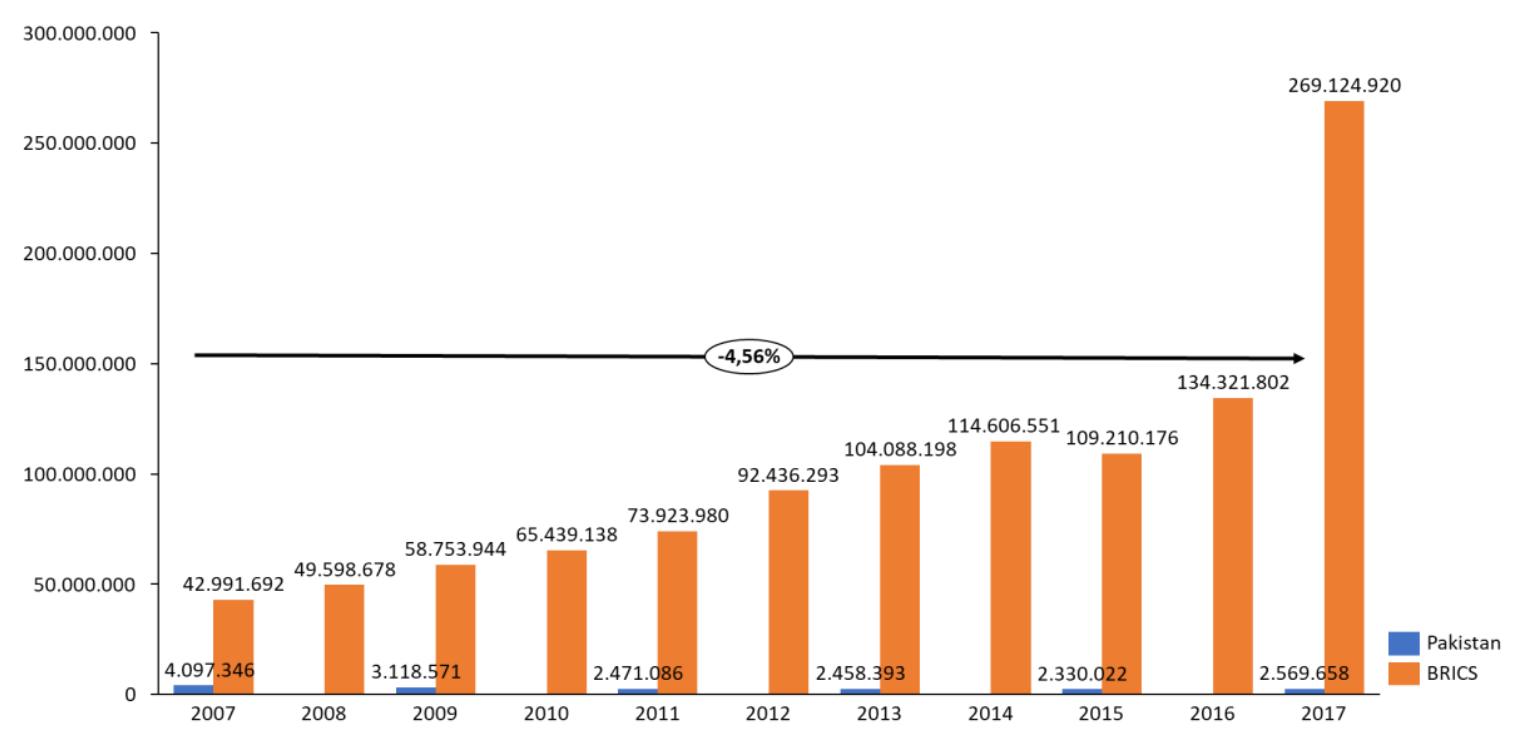

Teknolojik verimliliğin ve Ar-Ge potansiyelinin analizi için kullanılan en yaygın gösterge, Ar-Ge harcamalarının GSYİH içindeki oranıdır (Şekil 2). BRICS ülkelerindeki Ar-Ge harcamalarının GSYİH'daki oranı yıllık 4,38\% yükseliş ile büyürken, Pakistan'da \%9,39 yıllık düşüş ile 2017 yılının sonunda 0,24\% seviyesine gerilemiştir. Ayrıca kişi başına düşen Ar-Ge harcaması BRICS ülkelerinde 11,58\% ile yıllık gelişme göstererek 322\$'ın üzerine çıkmayı başarmıştır. Pakistan'da ise bu oran, yıllık $6,5 \%$ düşüşle $13 \$$ seviyesine kadar gerilemiştir (Şekil 3). Pakistan'daki Ar-Ge harcamalarında yaşanan düşüş trendi, Ar-Ge harcamalarının GSYİH içerisindeki payı ve kişi başına düşen Ar-Ge harcaması ile benzer düşüş trendi içerisindedir. Toplam nüfustaki büyüme oranı, Ar-Ge harcamalarındaki düşüşle karşılaştığı için Ar-Ge harcamaları üzerinde yapılan alternatif göstergelerde kendini derinleşen düşüş trendi ile göstermiştir. Makro ekonomik göstergeler, gelişen ve büyüyen nüfus göz önüne alındığında Ar-Ge yatırımları ile desteklenmezse sürdürülebilir büyüme yakalanamayacaktır. Büyüyen ekonomi ve nüfus ile orantılı olarak Ar-Ge yatırımları artırılmalı ve BRICS ülkelerinde yaşanan gelişmelere benzer yükseliş trendi yakalanmalıdır. 

Tabani)

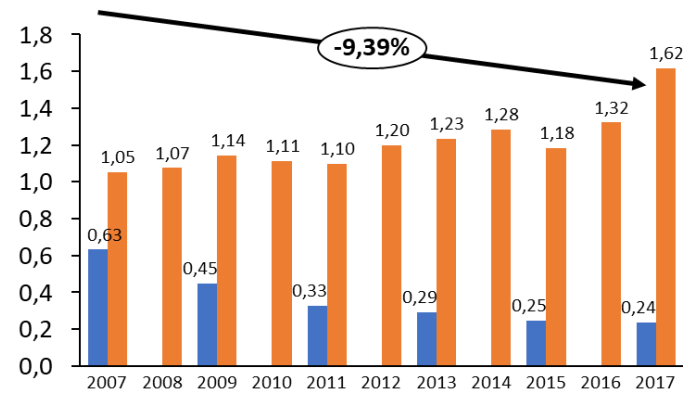

\subsubsection{Ar-Ge Yatırımlarının Kullanım Alanları}

Ar-Ge yatırımlarının yüksek öğrenim ve devlet tarafından gerçekleştirilmesi iki kritik unsurdur. Farklı politik destekler ile şekillenen ve sosyal tanınırlık seviyelerine göre değişen ulusal ekosistemin bu iki farklı unsuru, farklı büyüme oranlarına ve etkinlik seviyelerine yol açmaktadır. Pakistan'da farklı finansman yapılarının ve akışlarının olması, kamu sektöründeki organları sınıflandırmanın karmaşıklaşması nedeniyle Ar-Ge yatırımlarının kullanım alanlarına göre sınıflandırılmasını zorlaştırmaktadır. Daha ayrıntılı bir değerlendirme yapılabilmesi için ülkedeki BTY finansman yapısının yeniden gözden geçirilmesini gerekmektedir. (Osama, Hassan, Chattha, 2015).

Çalışmada kullanılan veri tabanları incelendiğinde BRICS ülkelerinin Pakistan'a göre BTY sistemine ait istatistiksel verileri ve raporları çok daha ayrıntılı ve doğru bir şekilde araştırdığı ve paylaştığı görülmüştür. Yüksek öğrenim harcamaları ve kamu harcamalarına ek olarak, BRICS ülkeleri özel sektör şirketleri ve kar amacı gütmeyen kuruluşların Ar-Ge yatırımlarını inceleyerek sınıflandırmayı ayrıntılandırmışlardır. Çalışma Pakistan özelinde tasarlandığı için yüksek öğrenim ve kamu tarafından gerçekleştirilen faaliyetler değerlendirilmiştir. Ancak lokasyon analizi için farklı bir konum kullanılmak istendiğinde ve veriye erişim sağlanabildiğinde daha ayrıntılı bir çalışma gerçekleştirilebilir.

Pakistan'da yükseköğretim kurumları tarafindan gerçekleştirilen Ar-Ge harcamaları oranı, 2007 yılından itibaren çeşitli dalgalanmalar ile beraber, 2011 yılında yaklaşık 625 milyon Amerikan dolarından, 2017 yılında yaklaşık 1.63 milyar Amerikan dolarına yıllık 17,33\% büyüme oranı ile ulaşmıştır (UNESCO İstatistik Enstitüsü Veri Tabanı). Aynı gösterge BRICS ülkeleri için değerlendirildiğinde yükseköğretim kurumlarının Ar-Ge harcamalarındaki yükseliş trendi, kamu tarafindan da benzer bir yükseliş ile desteklenmiştir (UNESCO İstatistik Enstitüsü Veri Tabanı). Fakat Pakistan'ın Ar-Ge harcamaları içerisinde pozitif etki yaratan yükseköğretim harcamalarındaki etki kamu harcamalarındaki azalış ile toplamdaki düşüş trendine engel olamamıştır. Pakistan benzer şekilde yükseköğretim harcamalarındaki sürekliliği sağlayarak, kamuya ait Ar- Ge harcamalarında da BRICS ülkelerinde gözlenen yükselişe benzer bir trendi yakalamak için çeşitli politikalar geliştirmelidir. Çeşitli kamu kuruluşlarının görevlerini yeniden tanımlamak, teşviklerin yapısını değiştirmek ve BTY

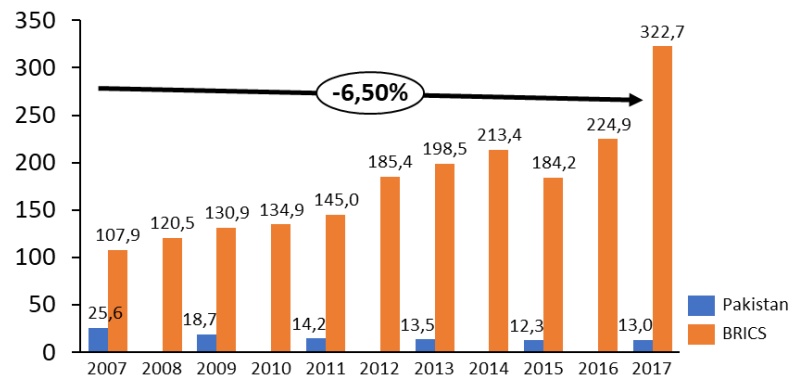

sistemine özel sektör katılımını artırmak alınabilecek önlemler arasında sayılabilir (Osama ve ark., 2015).

\subsubsection{Ar-Ge Yatırımlarının Kaynaklandı̆̆ Alanlar}

Pakistan'da, yükseköğretim tarafindan gerçekleştirilen ArGe harcamalarının finansmanındaki artı̧̧ eğilimi (2017'de 900.894.000 \$), kamu tarafindan gerçekleştirilen Ar-Ge harcamalarının finansmanındaki düşüş eğilimi (2017'de 1.589.310.000 \$) ile karşılaşmaktadır (UNESCO İstatistik Enstitüsü Veri Tabanı). Ar-Ge yatırımlarının kullanım alanları ve Ar-Ge yatırımlarının kaynaklandığı alanlar incelendiğinde izlenen trendler aynı yönlü ve benzer miktarlarda gerçekleşmektedirler. Ar-Ge performansını ifade eden finansal göstergeler arasındaki ilişki analiz aşamasında net bir şekilde görülmüştür. BRICS ülkelerindeki Ar-Ge harcamalarındaki istikrarlı yükseliş trendi tüm ölçekteki finansal göstergelerde görülmüştür.

\section{2. İnsan Kaynakları İstatistikleri - BTY Girdilerinin Ölçülmesi}

Bilgi ekonomisi geliştirmek, hızla değişen küresel koşullara kaliteli eğitim ile yanıt vermeyi gerektirir. Bilim, teknoloji, mühendislik, tekstil ve mimarlık / tasarım gibi alanlarda üniversitelere yapılacak yatırımlar, kalifiye insan kaynaklarına olan talebi karşılamak için gereklidir. Üretimdeki verimliliği ve katma değeri artırmak için gerekli insan kaynağı böylece karşılanmış olacaktır. Bu kapsamda Pakistan gelecek yıllarda gerçekleştirmek üzere planladığı yatırımları artırarak insan kaynağının gelişimine katkı sağlanmasını ve eğitim sektörünün teşvikler ile geliştirilmesini planlamaktadır (Pakistan Vision 2025 Report).

\subsubsection{Ar-Ge Personeli}

Pakistan'da toplam Ar-Ge personeli sayısı yıllık 3,84\% büyüme oranıyla 101.437 tam zamanlı çalışana (TZÇ) ulaşmıştır. BRICS ülkelerinde ise bu çıkış çok daha yüksek bir büyüme oranı ile 12,87\% olarak gerçekleşmiş̧ir (Şekil 4). Pakistan'ın BTY girdileri içerisinde insan kaynağındaki bu performansı, finansal göstergeler ile karşılaştırıldığında daha olumlu bir içgörü kazanmamıza imkan sağlamıştır. BRICS ülkelerindeki yükseliş, Pakistan'ın hedefleyebileceği örnek bir trend olarak görülebilir. 


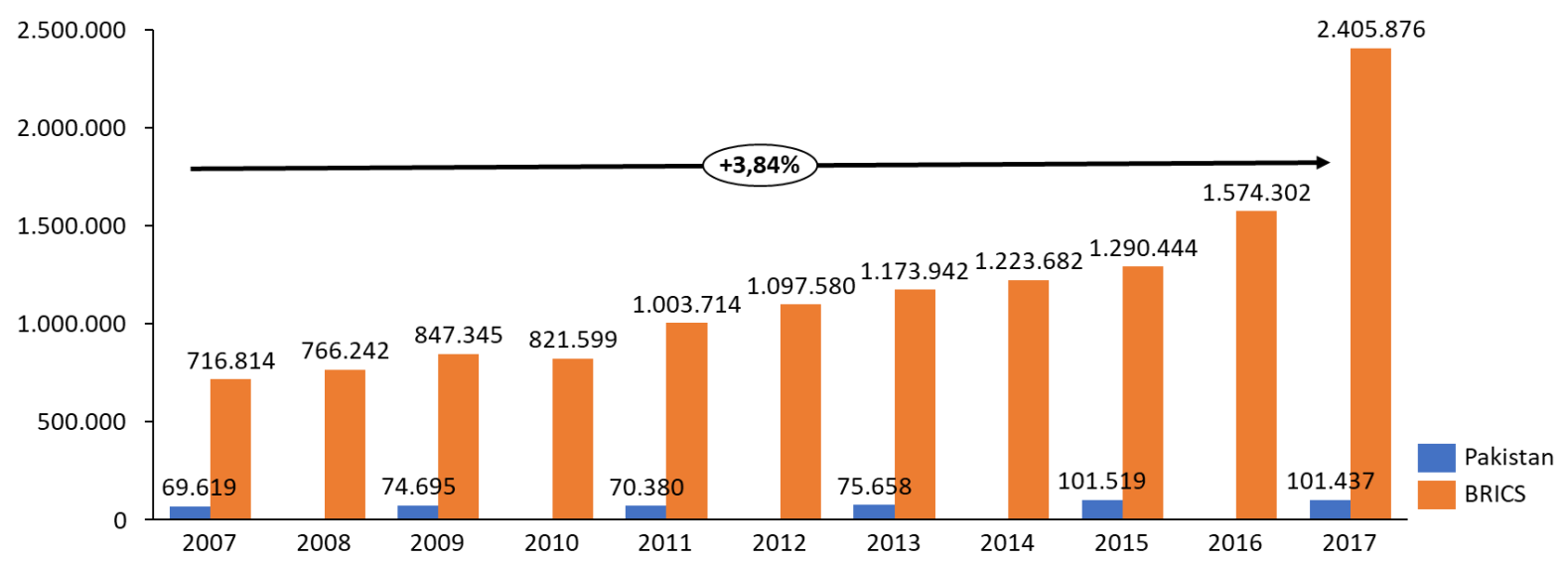

BRICS ülkelerinde milyon kişi başına düşen toplam Ar-Ge personelindeki yıllık büyüme oranı 5.94\% olarak gerçekleşmiştir (Şekil 5). Çalışan bin kişi başına düşen toplam Ar-Ge personeli sayısı ise yıllık 5,23\% büyüme oranı ile yükselmiştir (Şekil 6). Benzer yükseliş trendi Pakistan için de geçerlidir, fakat yıllık büyüme oranları daha düşük bir seviyede gerçekleşmiştir.
Milyon kişi başına düşen toplam Ar-Ge personeli sayısı 1,72\% yıllık büyüyerek 515 TZÇ; çalışan bin kişi başına düşen toplam Ar-Ge personeli sayısı ise $1,15 \%$ büyüme oranı ile 1,53 TZÇ olarak gerçekleşmiştir (Şekil 5,6). Milyon kişi başına düşen ArGe personeli sayısı, toplam Ar-Ge personeli ile benzer bir yükseliş trendi göstermektedir.

Şekil 5,3: Milyon kişi başına düşen Ar-Ge Personeli Sayısı, Bin çalışan başına düşen Ar-Ge Personeli Sayısı (TZÇ) (UNESCO Istatistik Enstitüsü Veri Tabanı)

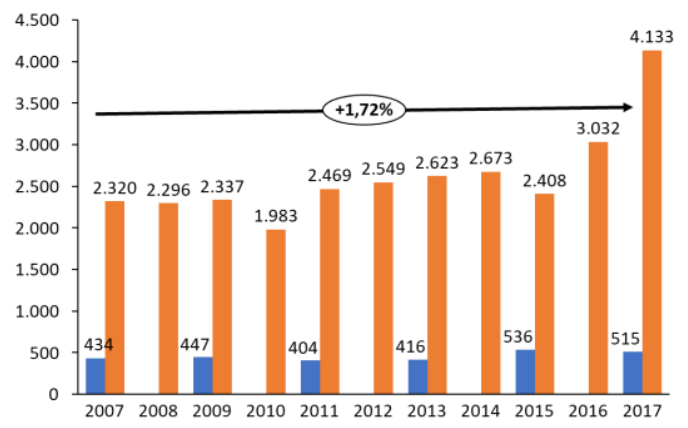

2011 yılından itibaren Pakistan'da yükseköğretim kuruluşlarında çalışan toplam Ar-Ge personeli sayısı yıllık 21,35\% artış oranı ile 76.643 TZÇ sayısına ulaşmıştır. Kamuda çalışan toplam Ar-Ge personeli sayısı ise yıllık 5,78\% düşüş oranı ile 24.794 TZÇ’a gerilemiştir. BRICS ülkelerinde ise yükseköğrenim kuruluşları, kamu, özel sektör ve sivil toplum kuruluşlarında sırasıyla hepsindeki toplam Ar-Ge personeli sayısı yükseliş göstermiştir (UNESCO İstatistik Enstitüsü Veri Tabanı). Pakistan'da yükseköğrenim kuruluşlarında gözlemlenen yükseliş trendi, kamu sektöründeki düşüş ve BRICS ülkelerindeki tüm sektörlerdeki yükseliş, Ar-Ge yatırımlarındaki trendler ile aynı seyri izlemektedir. BTY girdileri içerisindeki finansal kaynaklar ve insan kaynağındaki davranışların arasında doğrudan bir ilişki olduğu gözlemlenmiştir. Yapılan yatırımlar insan kaynağını etkilediğini söyleyebiliriz.

\subsubsection{Araştırmacılar}

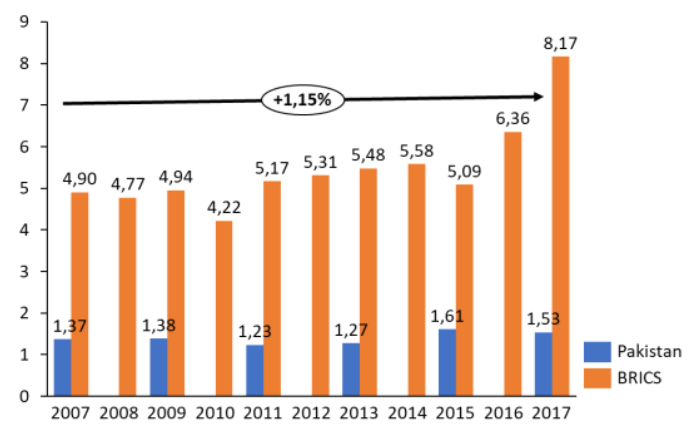

UNESCO İstatistik Enstitüsü'nün açıkladığı BTY istatistikleri; Ar-Ge personelini araştırmacı, teknisyen ve eşdeğer personel, diğer destek personeli olmak üzere üç ana başlık altında incelemektedir. Yazılım geliştirme süreçlerinde en etkili şekilde kullanılan insan kaynağı, araştırmacı olarak sınıflandırabileceğimiz insan kaynağı olacaktır. Bu nedenle çalışmamızda Ar-Ge personeli içerisindeki araştırmacılara ait göstergeler incelenmiştir. Pakistan'da toplam tam zamanlı çalışan araştırmacı sayısı, 10,23\% yıllık artış ile 2017'de 69.769 TZÇ'ye ulaşmıştır. BRICS ülkelerinde, Pakistan ile karşılaştırıldığında daha düşük bir yükseliş ile yıllık büyüme $7.87 \%$ olarak gerçekleşmiştir (Şekil 7). Yazılım geliştirme süreçlerinde aktif olarak kullanılacak ve şirketlerin dış kaynaklı yazılım lokasyonlarında ihtiyaç duyduğu araştırmacı sayısındaki hızlı yükseliş trendi Pakistan'ın kendisini diğer lokasyonlardan ayrıştırması için kullanabileceği önemli bir BTY göstergesi olarak değerlendirilmektedir. 


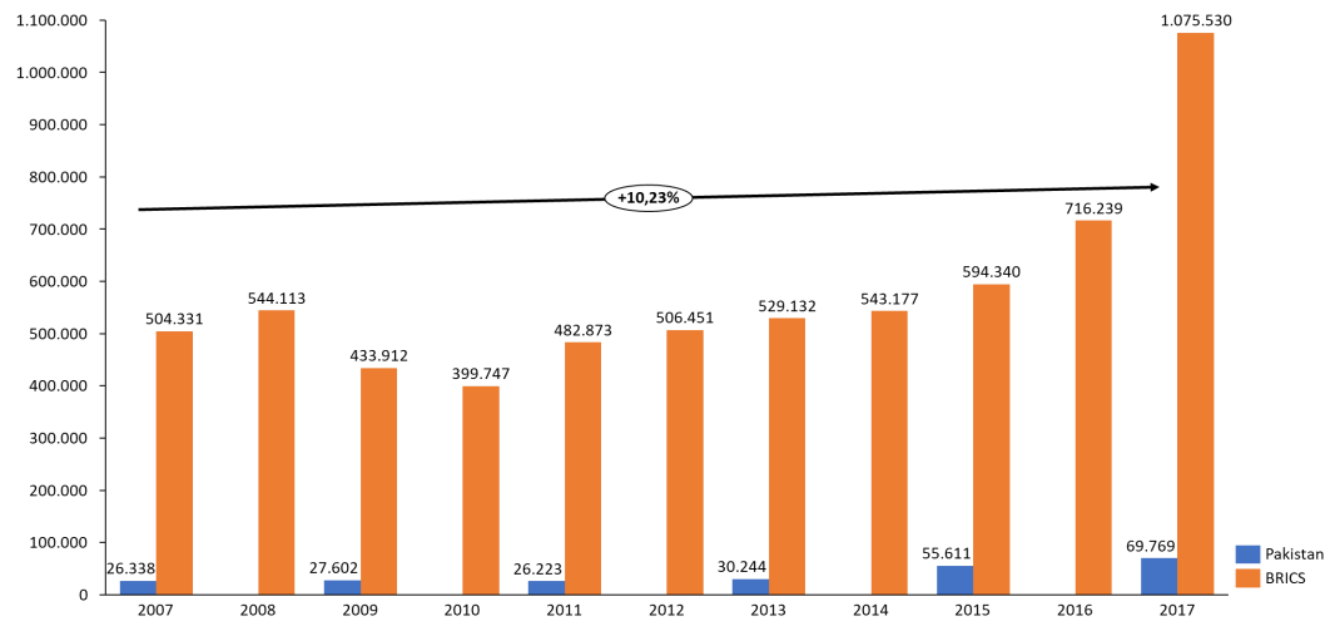

\subsubsection{Sektör bazlı Araştırmacıların Değerlendirilmesi}

Pakistan'da kamu sektöründeki toplam Ar-Ge personeli sayısındaki düşüş, benzer şekilde kamu sektöründe çalışan araştırmacılarda da 5,4\% yıllık küçülme oranı ile 5.138 TZÇ'ye gerilemiştir. Ancak bunun yanında yükseköğretim kuruluşlarında çalışan toplam araştırmacıların 2011 yılından itibaren 24,71\% yıllık artış ile 64.631 TZÇ sayısına ulaştığı gözlemlenmiştir. Araştırmacıların 92\%'den fazlası yükseköğretim kuruluşlarında çalışmaktadır.

Pakistan'da söz konusu yıllarda, yükseköğretim kurumlarını destekleyici araştırma ortamı oluşturmak için bir destek programları başlatılmıştır. Öğretmenlere yurtdışındaki araştırmacılarla iletişim kurma firsatı sunmak için yükseköğretim kuruluşları tarafından çok sayıda ortak araştırma işbirliği programı oluşturulmuştur. Ayrıca, 62 adet dijital kütüphane; ülke genelindeki üniversiteleri yabanc1 üniversitelerle iletişimini sağlayan akademik internet; üniversitelerin yüksek maliyetli ekipman alışverişi yapmalarına imkan sağlayan paylaşım programı; laboratuvarlara ve tesislere yapılan yatırımlar ile yükseköğretim kuruluşlarının BTY girdileri içerisindeki yeri genişletilmeye çalışılmıştır (Osama, Hassan, Chattha, 2015). Pakistan'ın yüksek öğretim kurumlarına yaptığı bu yatırımının etkileri, BTY girdilerinde hem finansal kaynaklarda hem de insan kaynağında görülmektedir.

2011 yılından sonra yaşanan yükseköğretim kurumlarındaki insan kaynağının gelişimi, araştırmacı sayısı ile ilgili

Şekil 8: Ar-Ge Çalışma Alanına Göre Mühendislik ve Teknoloji Alanında Çalışan Toplam Araştırmacı Sayısı (TZÇ) (UNESCO

\section{Istatistik Enstitüsü Veri Tabanı)}

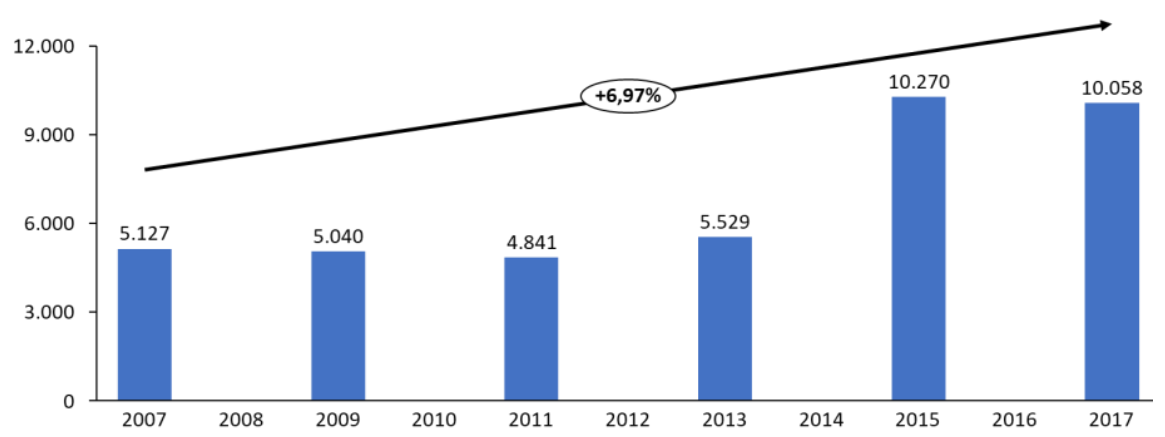

göstergelerde çok daha net gözükmektedir. Araştırmacı sayısındaki trendlerin toplam Ar-Ge personeli ve toplam Ar-Ge harcamalarına olan etkisi trendler incelendiğinde açık bir şekilde gözlemlenmektedir. Bunun yanında karşılaştırma yapılan BRICS ülkelerinde benzer şekilde gözlemlenen büyüme trendleri, araştırmacılar sektörel bazlı incelendiğinde de devam etmektedir.

\subsubsection{Mühendislik ve Teknoloji Alanındaki Araştırmacıların Değerlendirilmesi}

BTY politikalarının yazılım geliştirme süreçleri için bir diğer önemli yanı, politka hedefleri doğrultusunda bilim ve teknoloji üzerine çalışan insan kaynağıdır. Politika hedefleri ve yönelimlerinin lokasyonla beraber gelişmişlik derecesine göre de şekillenmektedir (Vithlani, 2019). Çalışma içerisinde farklı ölçeklerdeki göstergelerin yer alması, gelişmişlik düzeyini her seviyede gözlemleyebilmemize ve analiz edebilmemize olanak sağlamaktadır. Mühendislik ve Teknoloji alanındaki araştırmacıların incelenmesi diğer göstergelere nazaran daha ayrıntılı bir analiz imkanı sunmakta ve yazılım geliştirme süreçlerine olan etkisinin daha yüksek olduğu düşünülerek değerlendirilmiştir. BTY göstergeleri ile dış lokasyonların değerlendirilmesinde kullanılabilecek bu karar destek aracı organizasyon hedeflerine göre belirlenen ölçekte özelleştirilebilir. Yazılım geliştirme süreçlerinin değerelendirilmesinde, Ar-Ge faaliyetleri çalışma alanlarına göre sınıflandırıldığında, belirlenen kategorilerden Mühendislik ve Teknoloji alanı en uygun gösterge olarak seçilmiştir.
$\mathrm{Bu}$ çalışmada sırayla istatistikler genelden özele olacak şekilde incelenmiş ve aralarındaki ilişki analiz edilmiştir. Her lokasyon için analiz farklı bir aşamada sonlanabilir. Ayrıca yazılım geliştirme dişında başka bir alanda dış kaynak kullanarak lokasyon değerlendirmesi yapmak isteyen karar vericiler genelden özele ihtiyaçlarına göre farklılaştırarak bu analizi gerçekleştirip karar destek aracı olarak kullanmaya devam edebilirler. Pakistan'da 6,97\% yıllık büyüme oranı ile 
mühendislik ve teknoloji alanında çalışan toplam araştırmacı sayısı 10.058 tam zamanlı çalışana ulaşmıştır (Şekil 8). Mühendislik ve Teknoloji alanında çalışan araştırmacı sayısındaki bu insan kaynağı artışı, dış kaynaklı yazılım lokasyonu değerlendirmemizde Pakistan lehine olumlu bir içgörü sahibi olmamızı sağlamıştır.

BTY girdisi olarak insan kaynağı, ulusal BTY sisteminin Ar-Ge ve yenilik yatırımları ile birlikte en önemli girdisidir. İncelenen on yilda Pakistan'ın Ar-Ge harcamalarında yakalayamadığ 1 yükseliş trendini insan kaynağı açısından sağlayabildiğini görmekteyiz. Yatırım ile insan kaynağının birlikte büyüme gösterdiği BRICS ülkelerinde dış kaynaklı yazılım üssü olarak görülmelerini ve en önemli dış kaynak lokasyonları arasında sayılmalarını BTY göstergeleri ile açıklayabilmekteyiz.

\subsection{IP İstatistikleri - BTY Çıktılarının Ölçülmesi}

Bilimsel araştırma ve teknolojik gelişmenin pratik etkisinin özel bir ölçüsü olarak, bu bir etki için gerekli veya yeterli bir şart olmamasına rağmen, patentleme sayılabilir. Y1llar boyunca, yeniliğin doğası sürekli değişmektedir ve gittikçe artan bir şekilde "açık" ve "işbirlikçi" modeller norm haline gelmektedir. $\mathrm{Bu}$ nedenle patent ve ticari marka istatistikleri, dış kaynaklı yazılım lokasyonlarını değerlendirirken incelediğimiz BTY göstergeleri arasında yer almıştır.

\subsubsection{Patent İstatistikleri}

BRICS ülkelerindeki patent başvuru sayısı yıllık 16,61\% büyüme oranıyla yerleşiklerde gözlemlenen yükselişin taban oluşturması ile doğrusal bir trend yakalamıştır. Yerleşikler 20,59\%, yerleşik olmayanlar 4,44\%, yurtdışı kaynaklı olanlar $16,54 \%$ yıllık büyüme oranı ile yükselişe katkı sağlamışlardır (Şekil 9). İncelenen 10 yıllık dönemde Pakistan'daki Toplam Patent Başvuruları incelendiğinde yıllık 2,16\% küçülme oranı ile dalgalı bir seyir gözlemlenmektedir. Pakistan'daki patent başvurularında yerleşik olmayanların tabanı etkilediği görülmektedir. Yerleşikler 13,14\% ve yurtdışı kaynaklı olanlar $9,69 \%$ yıllık büyüme oranıla büyürken, baz etkisi oluşturan yerleşik olmayanlar $6,23 \%$ y1llık küçülme oranıyla toplam patent sayısındaki düşüşün ana neden olduğu gözlemlenmektedir (Şekil 10).

\section{Şekil 9,10: Toplam Patent Başvuru Sayısı - Pakistan, BRICS Ülkeleri (Dünya IP Organizasyonu Veri Tabanı)}

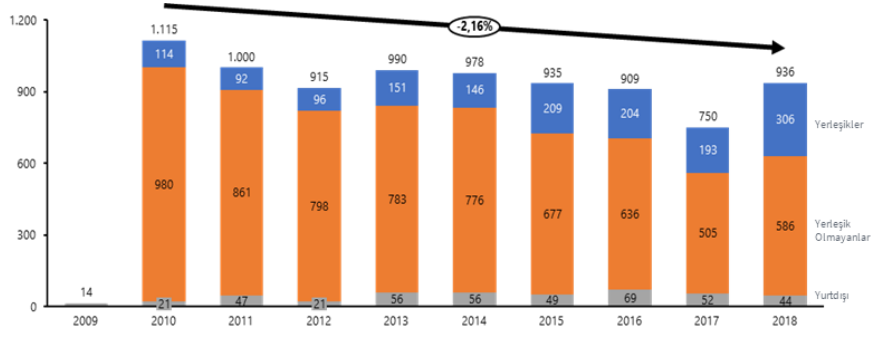

Pakistan'daki verilen patent sayısı istikrarlı bir seyir izlememektedir, ancak son 10 yılda 2,07\%'lik bir yıllık büyüme oranı göstermiştir. Patent başvurularında olduğu gibi verilen patent sayısında da yerleşik olmayanlar büyük çoğunluğu sağlamakta ve toplamda görülen azalışı etkilemektedir. Pakistan'daki patent başvurusu ve verilen patent sayılarının temeli çok uluslu şirketler gibi yabancı köklere sahip kişi ve kurumlara dayanmaktadır. Yerleşik olmayanların, yurtdışındaki talep sahiplerinin, Pakistan'da toplam verilen patent sayısında önemli bir yer alması dış kaynaklı geliştirme süreçlerinde Pakistan'ın mevcut durumu hakkında fikir sahibi olmamızı

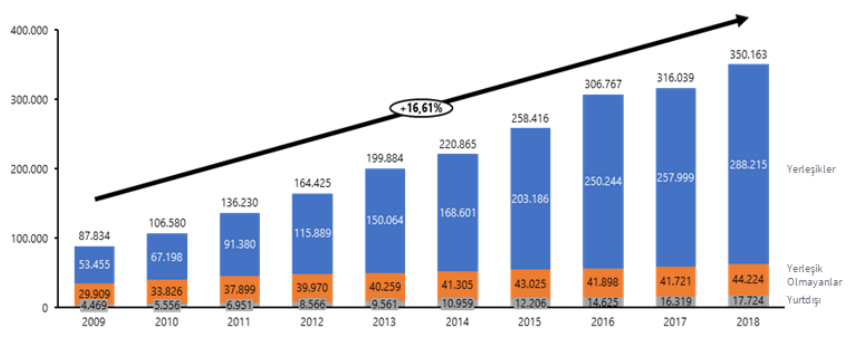

sağlamıştır. Ulaşılabilirlik ve maliyet nedeniyle patent sayısı Pakistan'da inovasyon derecesini doğru şekilde yansıtmayabilir ancak karar destek sistemimizde nedenselleştirebileceğimiz birtakım görüşler sağlayabilir. (Osama, Hassan, Chattha, 2015). $\mathrm{Bu}$ dalgalı ve düzensiz seyirde veri toplama aşamasında yaşanabilecek sorunlar göz önünde bulundurulmalı ve bu göstergenin kritik öneme sahip olduğu, iş ihtiyaçları ve lokasyonlarda ayrıca bir araştırma gereksinimi olabileceği unutulmamalıdır. Diğer taraftan, BRICS ülkeleri ise yıllık \%12,89 artış oranıyla düzenli büyüme ivmesini sürdürmüştür.

\section{Şekil 11,4: Toplam Verilen Patent Sayısı - Pakistan, BRICS ülkeleri (Dünya IP Organizasyonu Veri Tabanı)}
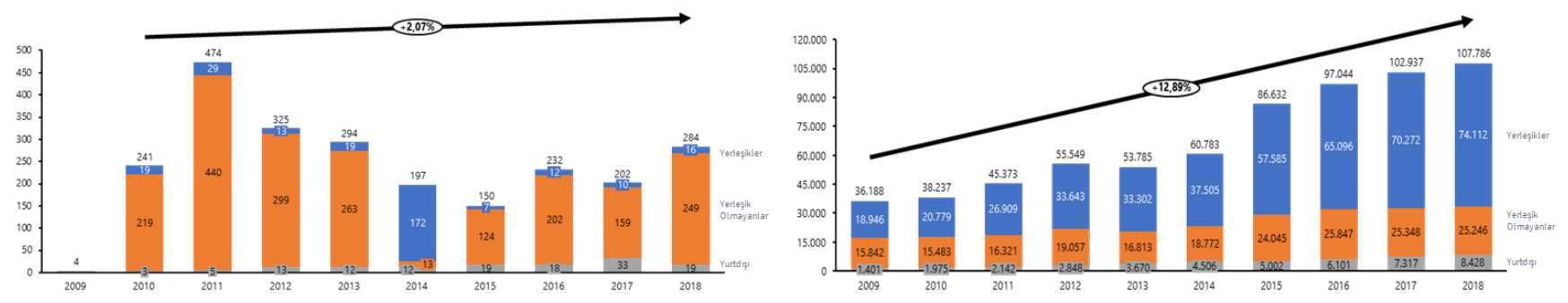

\subsubsection{Ticari Marka İstatistikleri}

Toplam Ticari Marka Uygulamalarında Pakistan yıllık 10,25\% büyüme oranı ile 40.415 sınıf sayısına ulaşmıştır. Benzer yükseliş trendi BRICS ülkelerinde de gözlemlenmiştir (yıllık $22,85 \%$ büyüme oranı). Ayrıca Pakistan'da son on y1llık periyotta yerleşiklerde $10,5 \%$, yerleşik olmayanlarda $9,46 \%$, yurtdışı kaynaklı olanlarda ise $9,66 \%$ yıllık büyüme oranı

toplamdaki yükseliş trendini desteklemiştir (Şekil 13). Marka başvuru istatistikleri ayrıntılı incelendiğinde bileşenlerde gözlemlenen yükseliş BRICS ülkelerinde de benzer şekilde gerçekleşmiştir. BRICS ülkelerinde yıllık 22,85\% artış oranı ile net bir büyüme görülmektedir (Şekil 14). Marka başvuruları incelendiğinde Pakistan'nın, BRICS ülkelerindeki yükseliş trendini yakaladığını ve söz konusu BTY çıktısında iyimser bir tablo çizdiğini söyleyebiliriz. 

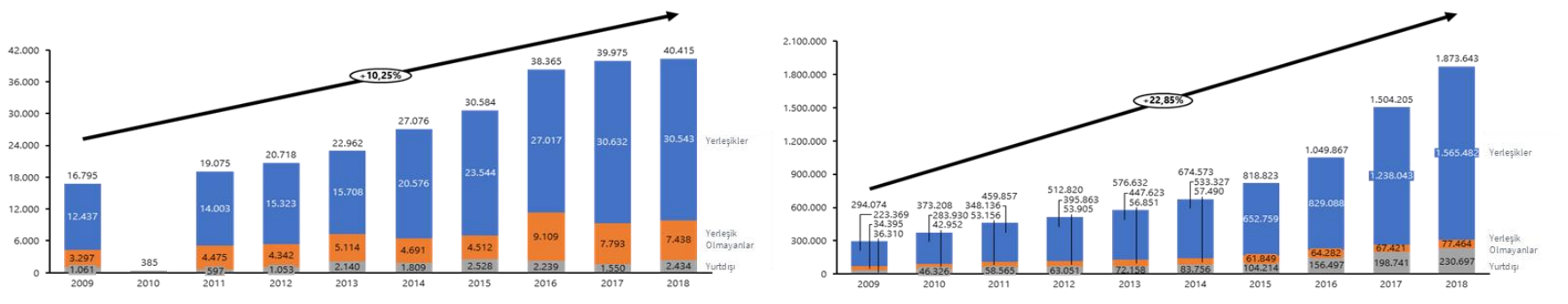

Şekil 15,16: Ticari Marka Kayıtlarında Belirtilen Sinıf Sayısı - Pakistan, BRICS ülkeleri (Dünya IP Organizasyonu Veri Tabanı)
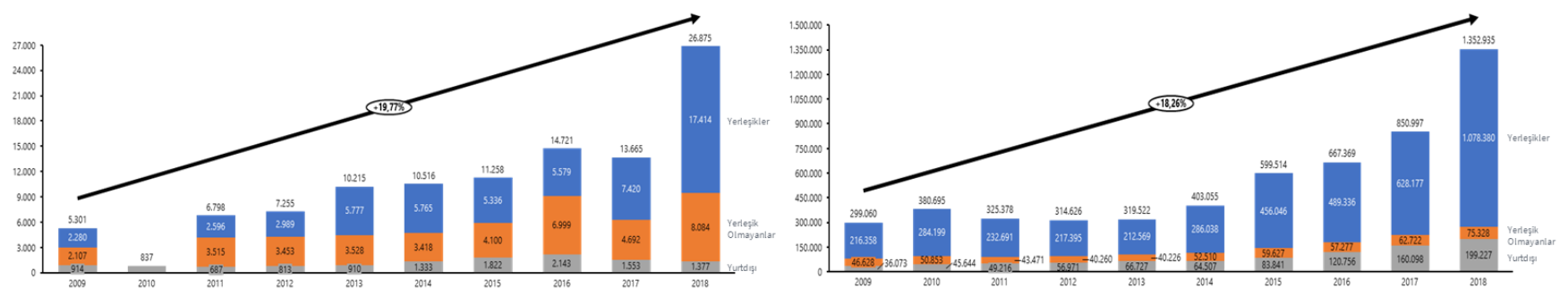

BRICS ülkelerinde IP istatistikleri doğrudan ve bölge ofisleri aracıllğıyla elde edilmektedir. Ancak Pakistan'da fikri mülkiyet hakları ile ilgili kurumlar ve organizasyonlar BRICS ülkelerinde ve gelişmiş ülkelerde olduğu şekilde aktif ve doğru bir işleyiş şekline sahip değildir. Bu nedenle, yalnızca patent ve ticari marka verileri karşılaştırılabilmiştir.

\subsection{Bilimsel Yayın İstatistikleri - BTY Çıktılarının Ölçülmesi}

Yazılım geliştirme süreçleri için lokasyon değerlendirmesinde mühendislik ve teknolojiye dayalı ölçümler en ayrıntılı BTY göstergeleridir. Bilimsel ve teknik dergi makaleleri, fizik, biyoloji, kimya, matematik, klinik tıp,

Şekil 17: Bilimsel ve Teknik Dergi Makaleleri (Dünya Bankası Veri Tabanı)

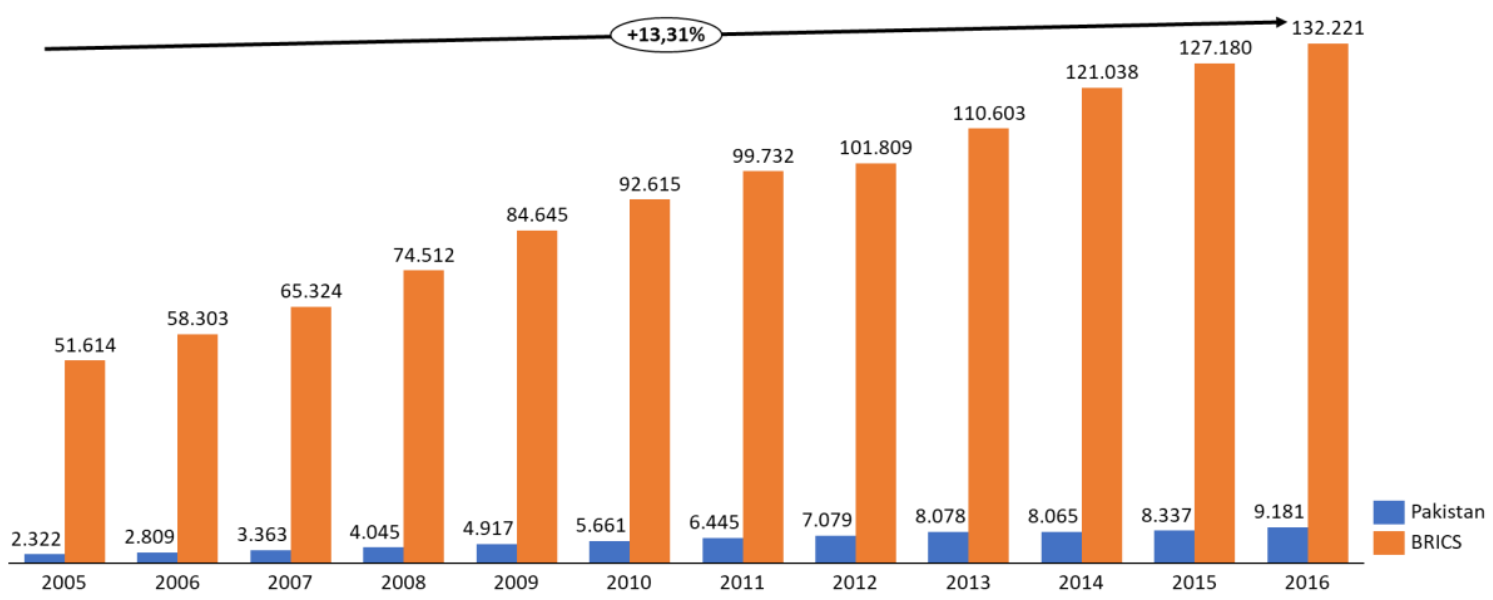

\section{5 İhracat İstatistikleri - BTY Çıktılarının Ölçülmesi}

Pakistan ve BRICS ülkelerinin son on yıllık yüksek teknoloji ihracatı incelendiğinde, dalgalı bir seyir gözlemlenmektedir. Bu dalgalı seyre rağmen Pakistan, yüksek teknoloji ihracatında $3,14 \%$ yıllık artış oranı yakalayabilmiştir. biyomedikal araştırma, yer ve uzay bilimlerinin yanında mühendislik, teknoloji alanlarında yayınlanan bilimsel ve teknik makaleleri içerir. Ayrıca çeşitli alanlardaki bilimsel yayınlar doğrudan ya da dolaylı olarak birbirlerini destekler yapıdadırlar. $\mathrm{Bu}$ bilgilerin 1şı̆̆ında Pakistan'da bilimsel yayın istatiskleri incelendiğinde y1llık 13,31\% büyüme oranı ile 9181 makale yayınlandığı görülmektedir (Şekil 17). BRICS ülkelerindeki yükseliş Pakistan'ın gerisinde yıllık $8,93 \%$ büyüme oranı ile gerçekleşmiştir. BTY girdilerinde yer alan insan kaynağındaki olumlu gelişmeler ve yükseliş trendlerinin, BTY çıtıllarından biri olan bilimsel yayınlardaki büyüme oranlarını desteklediği görülmektedir. 

Tabani)

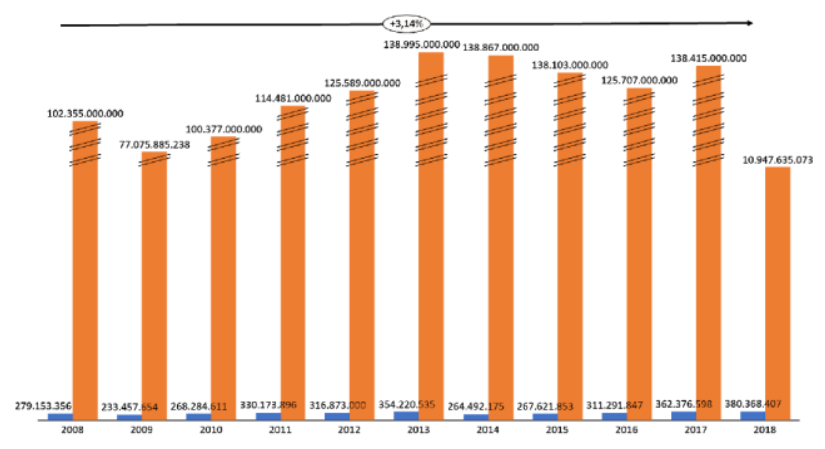

Yazılım geliştirme süreçlerinin yüksek teknoloji ihracatı olarak değerlendirilmesi ve altyapısal olarak benzer ürünlerin yer aldığı yüksek teknoloji verilerinin Pakistan lehine olumlu sonuçlar vermesi, karar vericilerin yazılım geliştirme süreçlerinde dış kaynak kullanırken potansiyel lokasyon değerlendirmelerinde Pakistan'1 avantajlı bir konumda görmemize olanak sağlayacaktır.

\section{Sonuç}

Bilim ve teknolojiyi desteklemek, Ar-Ge potansiyelinin ve dolayısıyla ulusal inovasyon sistemine yönelik politikaların geliştirilmesi, Pakistan'1 diğer ülkeleri taklit eden bir konumdan yeniliği getiren ve yüksek teknoloji ihracatını destekleyen bir konuma ulaştıracaktır. Belirli kilit sektörlerde teknolojiler doğru bir şekilde tatbik edilerek uzmanlaşma yoluna gidilebilir. Sonuç olarak, Pakistan ulusal bir teknoloji ve inovasyon sistemini yürütebilir. Bununla birlikte ulusal bir inovasyon sistemi bağlamında bu firsatların geliştirilmesine rehberlik etmek için, politik bir temel şeklinde, devlet müdahalesi gereklidir (Khattak, Baseer, Bajwa, 2009). Bilim, teknoloji ve yenilikçilik yeteneklerindeki gelişimin yalnızca yükseköğretimin takdirine bırakılamayacağı görülmeli ve kamu, yükseköğretim ve sanayi işbirliklerinden doğabilecek firsatlar değerlendirilmelidir.

Yazılım geliştirme süreçleri sonunda elde edilen yüksek teknoloji ürünlere ait verilerinin Pakistan lehine olumlu sonuçlar vermesi, karar vericilerin yazılım geliştirme süreçlerinde dış kaynak lokasyonlarını değerlendirirken Pakistan'1 olumlu değerlendirmelerine vesile olmuştur. Özellikle mühendislik ve teknoloji alanında çalışan araştırmacı sayısındaki önemli artış yazılım geliştirme sürecinin dış kaynak kullanımı ile Pakistan'da gerçekleştirilmesi için bizlere olumlu bir içgörü sağlamaktadır. Pakistan'da dış kaynak kullanımı değerlendirilirken, doğru stratejiler izlenerek kilit alanlardaki teknolojilerde uzmanlaşma yoluna gidilebilir. Pakistan'ın ulusal teknolojik sisteminin yanında ulusal yenilikçilik sistemindeki güncellemeler düzenli takip edilmelidir.

Çalışmada yer alan istatistikler ve analizler, insan kaynağının ve finansal kaynakların verimli bir şekilde kullanılabilmesi için BTY politikasının başarılı bir şekilde yürütülmesinin önemini göstermektedir. İncelenen dönem göz önüne alındığında Pakistan, BTY performansı ve çıktılar üzerindeki olumlu etkisini devam ettirmek için Ar-Ge yatırımlarını ve Ar-Ge personeli sayısını artırmalıdır. Bilimsel yayınlar ve patent sayılarındaki önemli ilerlemeler, sürdürülebilirlik için BTY girdileri ile desteklenmelidir. Pakistan'ın ve BRICS ülkelerinin karşılaştırılmalı BTY göstergelerindeki performans eğilimlerinden anlaşıldı̆̆ı üzere,

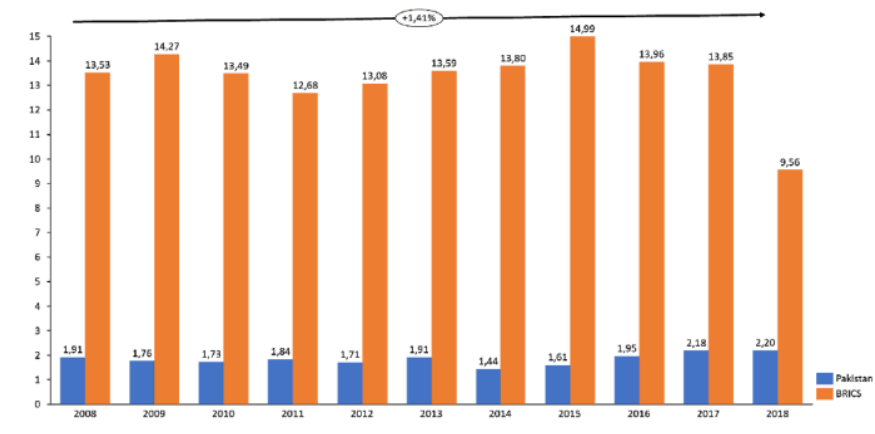

bir BTY atılımı yapılabilmesi için Ar-Ge yatırımları ve insan kaynağında yukarı yönlü trend yakalanmalıdır. BRICS ülkelerinden elde edilen ortalama değerler bu yukarı yönlü çıkışın ulaşılabilir bir hedef olduğunu göstermektedir. Bu ülkelerdeki benzer politikalar Pakistan'a göre özelleştirilmeli ve kamu öncülüğünde özel sektörün de desteği alınarak hayata geçirilmelidir. Pakistan'ın BTY çıktılarında yakaladığı performansı devam ettirebilmesi için BTY girdilerinin iyileştirilmesine yönelik aksiyonlar alması gerekmektedir.

Tüm bu analiz, öneri ve bulguların sonucunda Pakistan'ın bir dış kaynaklı yazılım geliştirme lokasyonu olarak potansiyeli ortaya konmuştur. Bu çalışma, inglizce dilinde Bandırma Onyedi Eylül Üniversitesi tarafından düzenlenen Uluslararası Bilimsel Araştırmalar ve Yenilikçi Çalışmalar Sempozyumu (ISSRIS'21)'nda sunulan bildirinin genişletilmiş ve türkçe dilinde hazırlanmış halidir. BTY göstergelerinin çeşitli ölçeklerde özelleştirilmesi ve lokasyon seçiminin şirket planlarında yer alan alternatif lokasyonlar özelinde revize edilmesiyle bu karar destek aracı yeniden tasarlanabilir.

\section{Kaynakça}

Ansal, H., Yıldırım, N., \& Yıldırım, H., (2012). An Agenda For Developing Countries For Improvement Of Innovation Related Statistics: Comparison Of Turkey With Developed Countries' Statistics. IAMOT 2012, Hsinchu, Taiwan

Gartner Inc. (n.d.). Compound Annual Growth Rate (CAGR). 1 Aralik $2019 \quad$ tarihinde https://www.gartner.com/en/informationtechnology/glossary/cagr-compound-annual-growth-rate adresinden erișildi.

Ishenko, O., (2005). Outsourcing Of Software Development. 26 Ekim $2019 \quad$ tarihinde https://pdfs.semanticscholar.org/75f9/0e856137843bd4bca5f $7300 \mathrm{fb} 85 \mathrm{e} 5 \mathrm{e} 58 \mathrm{ce} 1 \mathrm{e} . \mathrm{pdf}$ adresinden erişildi.

Khattak M., Baseer M., \& Bajwa M., (2009). National Innovation System and the Need for an Upgradation Policy for Innovative and R\&D Capabilities in Pakistan, Journal of Quality and Technology Management.

Liu, S., (2019). Topic: IT Outsourcing Industry - Statistics \& Facts. 26 Ekim 2019 tarihinde erişildi.

Longwood J., Ng F., Lo T., Roy A., Mishra D., Tang T., ve ark. (2015). Leading Offshore Services Locations in Asia/ Pacific Smaller Countries Gain Traction. Gartner Inc. 28 Ekim 2019 tarihinde erişildi.

Longwood, J., Barton, N., Stanley, A., \& Karamouzis, F. (2017). Evaluate Offshore/Nearshore Countries for Outsourcing, Shared Services and Captives Worldwide. Gartner Inc. 24 Ekim tarihinde erişildi. 
Osama A., Hassan S., \& Chattha K., (2015). The Pakistan Development Review, 54(2). doi: 10.30541/v54i2

Roy A., Longwood J., \& Huntley H., (2008). Analysis of Pakistan as an Offshore Services Location. Gartner Inc. 24 Ekim tarihinde erişildi.

S. Islam, M. M. A. Joarder and S. H. Houmb, "Goal and Risk Factors in Offshore Outsourced Software Development from Vendor's Viewpoint," 2009 Fourth IEEE International Conference on Global Software Engineering, Limerick, 2009, sayfa: 347-352, doi: 10.1109/ICGSE.2009.54.

S. U. Khan, M. Niazi and R. Ahmad, "Critical Success Factors for Offshore Software Development Outsourcing Vendors: A Systematic Literature Review," 2009 Fourth IEEE International Conference on Global Software Engineering, Limerick, 2009, sayfa: 207-216, doi: 10.1109/ICGSE.2009.28.

Schwachula, A., Seoane, M. V., \& Hornidge, A. K. (2014). Science, technology and innovation in the context of development. Bonn: Department of Political and Cultural Change Center for Development Research, University of Bonn.

Secretariat Ministry of Planning, Development \& Reform Government of Pakistan. (n.d.). Pakistan Vision 2025 Report. Islamabad.

Sedera, D., Lokuge, S., Krcmar, H., Srivastava, S. C., \& N., R. M. (2014). The Future of Outsourcing in the Asia-Pacific Region: Implications for Research and Practice-Panel Report from PACIS 2014. Communications of the Association for Information Systems, 35

The World Bank Data Bank. (n.d.). 26 Ekim 2019 tarihinde https://databank.worldbank.org/ adresinden erişildi.

Türkiye Bilimsel ve Teknolojik Araştırma Kurumu, Bilim, Teknoloji ve Yenilik Politikaları Daire Başkanlığı. (2011). Türkiye Bilim, Teknoloji ve Yenilik Sistemi ve Performans Göstergeleri Raporu.

UNESCO Institute for Statistics (n.d.). UIS Statistics. 26 Ekim 2019 tarihinde http://data.uis.unesco.org/ adresinden erişildi.

United Nations, Economic and Social Commission for Asia and the Pacific (ESCAP). (2018). Evolution of Science, Technology and Innovation Policies for Sustainable Development: the Experiences of China, Japan, the Republic of Korea and Singapore.

Vithlani, H. (n.d.). An empirical study of THE UK INNOVATION SYSTEM. [Available online at: http://www.oecd.org/science/inno/2380078.pdf], 24 Ekim 2019 tarihinde World Intellectual Property Organization. (n.d.). https://www3.wipo.int/ipstats/ adresinden erişildi.

Zhao, X., Wang, D., Xiao, Y., Dong, Q., Huo, H., Ma, Z., et.al. (2018). Forecast and Evaluation of Innovation Capabilities and Review of STI Cooperation of BRICS. Research Series on the Chinese Dream and China's Development Path BRICS Innovative Competitiveness Report 2017, sayfa: 330. doi: 10.1007/978-981-10-8078-4_1x" 